\title{
CORONAVIRUSES: DIAGNOSTIC APPROACHES FOR COVID-19
}

\author{
Rabin Gyawali ${ }^{1}$, Khim Dhoj Karki ${ }^{2}$, Ravin Bhandari ${ }^{3}$, Balram Neupane ${ }^{2}$, \\ Rubee Regmi Kafle ${ }^{2}$, Dhakaraj Pant ${ }^{4}$, Ram Bahadur Khadka ${ }^{5 *}$
}

\footnotetext{
${ }^{1}$ Department of Basic Science, Nepal Sanjivani Institute of Health Science,Council for Technical Education and Vocational Training (CTEVT), Nepal-00977

${ }^{2}$ Department of Laboratory Sciences, Faculty of Health Science, Crimson College of Technology (Pokhara University), Nepal-00977

${ }^{3}$ Department of Pharmacy, Faculty of Health Science, Crimson College of Technology affiliated to Pokhara University, Devinagar-11, Butwal, Nepal

${ }^{4}$ Department of Laboratory Sciences, Faculty of Health Science, Pokhara University, Dhungepatan, Nepal-00977

${ }^{5}$ Department of Laboratory Sciences, Faculty of Health Science, Crimson College of Technology (Pokhara University), Mayadevi Technical College, Faculty of Laboratory Sciences (PurbanchalUniversity),Nepal-00977
}

Received - August 24, 2020; Revision - September 09, 2020; Accepted - September 27, 2020

Available Online - October 08, 2020

DOI: http://dx.doi.org/10.18006/2020.8(Spl-1-SARS-CoV-2).S09.S20

\author{
KEYWORDS \\ BALF \\ CRISPR \\ COVID-19 \\ Diagnosis \\ GeneXpert \\ MALDI-MS \\ SARS-CoV-2
}

\begin{abstract}
Severe acute respiratory syndrome coronavirus2 (SARS-CoV-2) belongs to the beta corona virus genera of the Coronaviridae family, which is a pathogenic virus that causes coronavirus disease 2019 (COVID-19) and is responsible for the ongoing pandemic affecting more than 210 countries. The virus has currently posed a global threat to the human population and demands the urgent need for sensitive and effective methods of diagnosis. Real-time reverse transcription polymerase chain reaction (RT-PCR) is currently used as a gold standard technique for detecting and quantifying the transcript of viral ribonucleic acid. Yet many factors are essential for successful COVID-19 diagnosis, including sample sources, amount of viral load, isolation of ribonucleic acid, and the selection of the molecular targets. Although broncho alveolar lavage fluid (BALF) and sputum sample contain a high viral load with a high diagnostic value, they cannot be collected from mild to asymptomatic cases, therefore nasopharyngeal swab is considered better and is collected in all cases that contain a viral load significantly, whereas the use of blood and faecal specimens needs further examination with respect to systemic infection and viral shedding. Furthermore, rapid diagnostic test, clustered regularly interspaced short palindromic repeats (CRISPR)-based testing, chest computerized tomography (CT) scans, matrix- assisted laser desorption/ionization mass spectrometry (MALDI-MS), reverse transcriptional loop-mediated isothermal amplification (LAMP), point of care (POC) testing and genexpert recently tool may help with COVID-19 diagnosis. In this review, we focus on diagnostic approaches for effective detection of SARS-CoV-2 infection.
\end{abstract}

* Corresponding author

E-mail: rambahadurkhadka00@gmail.com (Ram Bahadur Khadka)

Peer review under responsibility of Journal of Experimental Biology and Agricultural Sciences.

Production and Hosting by Horizon Publisher India [HPI] (http://www.horizonpublisherindia.in/).

All rights reserved.
All the articles published by Journal of Experimental Biology and Agricultural Sciences are licensed under a Creative Commons Attribution-NonCommercial 4.0 International License Based on a work at www.jebas.org.

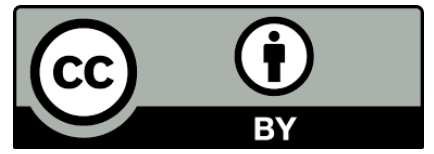




\section{Introduction}

Corona viruses are members of the Coronaviridae family which includes 2 subfamilies called Letovirinae and Orthocoronavirinae, with 4 genera as alpha, beta, gamma and delta corona virus (Siddell, 1995; Kasmi et al., 2020). Especially two forms of alphacoronavirus (229E and NL63) and two forms of betacoronavirus (OC43 and HKU1) are generally human pathogens and cause the common cold. Gamma and deltacorona viruses generally cause disease in avian species and rarely in mammals (Siddell, 1995; Kasmi et al., 2020; Shereen et al., 2020). Two other varieties of betacoronavirus include severe acute respiratory syndrome coronavirus-1 (SARS-CoV-1) and Middle East respiratory syndrome (MERS-CoV) which are highly pathogenic to humans (Siddell, 1995; Amanat \& Krammer, 2020).

Under electron microscope observation, the coronavirus appears to be surrounded by a uniquely shaped solar crown. In Latin Corona means crown or halo. They are the global emerging viruses that causes diseases ranging from mild symptoms of common flu, and influence more serious human diseases such as SARS and MERS (Mahy \& Van Regenmortel, 2010; Kasmi et al., 2020; Shereen et al., 2020). Previous studies and research have shown that these viruses emerged as a new strain: SARS-CoV-2 originally transferred from animals to humans had not previously been identified in humans, but transmission from human-to-human has so far been confirmed. Although SARS is transmitted by civet cats and MERS by camels had previously been identified in humans respectively (Kasmi et al., 2020).

On December 31, 2019, the WHO (World Health Organization) decided on a dark and progressive type of pneumonia in Wuhan, China, as a public health emergency of international interest. On February 11, 2020, they termed the disease as COVID-19. On the same day, Committee on Taxonomy of Viruses (ICTV) appointed the new corona virus as SARS-CoV-2, which also belongs to the beta-coronavirus genera that contain huge $30+$ kbsingle strand RNA genome encryption positive sense for various open reading frames (orf) (Shereen et al., 2020; Amanat \& Krammer, 2020). The established determination claims that $2 \%$ of people are healthy transmitters of this virus and responsible for acute respiratory infections in about 5\% -10\% (Siddell, 1995; Shereen et al., 2020; Cascella et al., 2020).

\section{Taxonomy}

The Coronaviridae family, Nidovirales order, includes two kinds of viruses: Coronavirus and Torovirus (Siddell, 1995; Kasmi et al., 2020). Most pathogens that infect humans and animals are like corona viruses, while toroviruses are also detected in human stools with unclear mechanisms and in animals that cause diarrhea. Initially, experts from the ICTV classified these viruses into 3 groups which are based on the antigenic relationship of the morphological characteristics of the virus, including spikes (S), membrane (M) and nucleocapsid proteins $(\mathrm{N})$ and other studies make a more solid classification based on genetic phylogeny (Drexler et al., 2014; Kasmi et al., 2020). Group 1 corona viruses are HCoVs229E and NL63, group 2 are OC43, HKU-1 and SARS. Group 3 corona viruses are found mainly in avian species. Members of the identical groups and others different groups show close genetic recombination which provides greater genetic diversity for corona viruses (Mahy \& Van Regenmortel, 2010; Drexler et al., 2014; Kasmi et al., 2020; Walls et al., 2020).

SARS coronavirus animal reservoirs are the source of the recognition of various bat coronaviruses in groups 1 and 2 which have phylogenetics almost similar to different mammalian corona viruses (Kasmi et al., 2020). Many previous studies and research have suggested that bat corona viruses are the ancestors of many mammalian corona viruses. Over the past 200 years, studies have shown that the common cold causative agents are $\mathrm{HCoV}, 229 \mathrm{E}$ and OC43 as universal endemic in humans species crossed from their animal reservoirs such as bats and cattle for humans, producing new viral diseases (Siddell, 1995; Drexler et al., 2014; Shereen et al., 2020). At intervals, the corona virus infecting wild life changed and become a novel corona virus that can infect humans. These newely developed CoVs can be very critical and occasionally produced pneumonia. Pneumonia is a fatal condition in which the liquid conforms to the lungs (Drexler et al., 2014).

Recently these three types of new corona viruses appeared in the following generation (Siddell, 1995; Drexler et al., 2014; Peeri et al., 2020).

- SARS (severe acute respiratory syndrome), a crucial and increasingly devastating respiratory disease. It was mainly found in China in 2002 and spread all over the globe. A worldwide exertion serves to rapidly contain the spread of the illness. No new protests have been announced in any place since 2004 in world.

- MERS (Middle East Respiratory Syndrome), a crucial breathing disease that was mainly found in Saudi Arabia in 2012 and has circulate to about 27 countries. Just two cases haves been declared in the United States. All manifestations haves been related to travel or accommodation on the Arabian Peninsula or in its entirety.

- COVID-19 (Corona virus disease 2019), It was registered in late 2019 in the capital city of Wuhan, Chinese Hubei province. The majority of the infections were earlier seen in China or as related to travel from Wuhan city to other countries. Thereafter, COVID-19 rapidly spread to more than 210 countries (Europe, Asia and Africa and across the globe) and posed high health threats and challenges (Dhama et al., 2020a; Malik et al., 2020). The epidemic is closely followed by the Center for Disease Control 
Table 1 Comparison of the characteristics between the new corona virus, SARS-CoV-1 and MERS-CoV.

\begin{tabular}{|c|c|c|c|}
\hline Characteristics & SARS-CoV-2 & SARS-CoV-1 & MERS-CoV \\
\hline Subgenus & Sarbecovirus (Lineage B/ $\beta b$ ) & Sarbecovirus (Lineage B/ $\beta b$ ) & Merbecovirus (Lineage $\mathrm{C} / \beta \mathrm{b}$ ) \\
\hline Phylogenetic Origin & Clade I & Clade IIb & Clade II \\
\hline Date/Place of Origin & December,2019/Wuhan, China & $\begin{array}{l}\text { November, 2020/ Guangdong, } \\
\text { China }\end{array}$ & June 2012/Jeddah, Saudi Arabia \\
\hline Nature Reservoir & Bats & Horseshoe bats & Bats \\
\hline Intermediate Host & Pangolin & Palm Civets & Camel \\
\hline Terminal Host & Humans & Humans & Humans \\
\hline Reproduction Number & $2.2-3.28$ & $2.0-5.0$ & Less than 1 \\
\hline Mortality Rate & $3-3.5 \%$ & $9.6 \%$ & $35.5 \%$ \\
\hline Disease & $\begin{array}{l}\text { Corona Virus Disease } 2019 \\
\text { (COVID-19) }\end{array}$ & $\begin{array}{l}\text { Severe Acute Respiratory } \\
\text { Syndrome (SARS) }\end{array}$ & $\begin{array}{l}\text { Middle East Respiratory Syndrome } \\
(\text { MERS) }\end{array}$ \\
\hline Functional Cellular & $\begin{array}{l}\text { Angeotensin converting Enzyme } \\
2 \text { (ACE2) }\end{array}$ & $\begin{array}{l}\text { Angeotensin converting Enzyme } 2 \\
\text { (ACE2) }\end{array}$ & Dipeptidyl Petidase 4 (DPP4/CD4) \\
\hline Antigen Presentation & MHCI and sometimes MHCII & MHCI and sometimes MHCII & MHCII \\
\hline Transmission & $\begin{array}{l}\text { Respiratory Droplets } \\
\text { Contacts with infected person } \\
\text { even asymptomatic ones } \\
\text { Via fomites } \\
\text { Nosocomial } \\
\text { High possibility via feco-oral } \\
\text { route. }\end{array}$ & $\begin{array}{l}\text { Respiratory Droplets } \\
\text { Contacts with infected person } \\
\text { Not via fomites } \\
\text { Feco-oral route }\end{array}$ & $\begin{array}{l}\text { Respiratory droplets } \\
\text { Contacts with infected person but is } \\
\text { limited } \\
\text { Not via fomites } \\
\text { Nosocomial } \\
\text { Not via feco-oral route }\end{array}$ \\
\hline $\begin{array}{l}\text { Immunopathological } \\
\text { event }\end{array}$ & $\begin{array}{l}\text { Acute respiratory distress } \\
\text { syndrome (ARDS) }\end{array}$ & $\begin{array}{l}\text { Acute respiratory distress syndrome } \\
\text { (ARDS) }\end{array}$ & $\begin{array}{l}\text { Acute respiratory distress syndrome } \\
\text { (ARDS) }\end{array}$ \\
\hline
\end{tabular}

(CDC) and the World Health Organization (WHO).Comparison of the characteristics between the new corona virus, SARS-CoV-1 and MERS-CoV are shown in Table 1 (Siddell, 1995; Mahy \& Van Regenmortel, 2010; Kasmi et al., 2020; Meo et al., 2020).

\section{Symptoms}

Starting from a respiratory disease, it presents a wide range of symptoms with incubation periods ranging from two to 14 days. Most infected humans show symptoms within 5-6 days, leading to some cases of asymptomatic conditions. Many studies indicate that symptoms such as pyrexia, cough, dyspnoea, sore throat, and headache are included in corona virus infections which are generally milder than SARS and MERS compared to COVID-19 (Cafekar \& Fielding, 2018; Dhama et al., 2020b; Petrosillo et al., 2020).

\section{Collection and Transport of Samples}

The sample must be collected from skilled person and taking into account all biosecurity mandates plus the use of personal protective equipment to prevent respiratory virus infection.

WHO recommends collecting samples through the upper respiratory tract (nasopharyngeal swab, oropharyngeal swab or washing) and the lower respiratory tract (sputum, bronchoalveolar lavage and endotracheal aspirate). Perhaps other clinical samples such as blood and feces can be collected (Cascella et al., 2020; WHO, 2020a).

Common impertinent faults (inadequate identification of the sample, insufficient material, inadequate collection method, handling, shipping and storage, presence of harmful substances, etc.) deserve a particular focal point during the collection of the samples. Although the WHO has not issued a particular reference method for collecting respiratory specimens, the United States CDC proposes to collect nasopharyngeal and oropharyngeal specimens by applying germ free swabs with fibre or Dacron tip and an aluminium or plastic shaft (Lippi et al., 2020).

To collect nasopharyngeal samples, the CDC supported the introduction of a swab into the nostrils, aligned with the palate and held for a few seconds for its absorption and instantaneous positioning in a sterile tube with 2-3 $\mathrm{ml}$ of viral transport medium (VTM ). Similarly to the collection of oropharyngeal samples, the CDC proposes to introduce a swab into the back of the pharynx, keeping it away from the tongue and placing it instantly in a sterile test tube having 2-3 $\mathrm{ml}$ of VTM (Lippi et al., 2020). To provide nasopharyngeal, oropharyngeal, bronchoalveolar lavage, endotracheal aspirate, VTM must contain antibiotic and antifungal supplements (WHO, 2020b). 
Table 2 Different collection, handling and transport samples for Covid-19

\begin{tabular}{|c|c|c|c|c|}
\hline Various Sample & $\begin{array}{l}\text { Used of Virus } \\
\text { Transport } \\
\text { medium (VTM) } \\
\text { or Extra medium }\end{array}$ & Shifting Process to lab & $\begin{array}{l}\text { Shifting of } \\
\text { Hazardous } \\
\text { materials }\end{array}$ & Remark \\
\hline $\begin{array}{l}\text { 1. Biopsy or autopsy of tissue from } \\
\text { lung }\end{array}$ & $\begin{array}{l}\text { Required or } \\
\text { Normal Saline } \\
\text { (NS) }\end{array}$ & $\begin{array}{l}\text { On ice pack. } \\
\text { In case of delay in processing sample in lab } \\
\text { of }>24 \text { hours apply frozen with dry ice }\end{array}$ & $\begin{array}{l}\text { Infectious } \\
\text { materials, } \\
\text { Class B. }\end{array}$ & \\
\hline 2. Bronchoalveolar lavage fluid (BALF) & Not Required & $\begin{array}{l}\text { On ice pack. } \\
\text { In case of delay in processing sample in lab } \\
\text { of }>24 \text { hours apply frozen with dry ice }\end{array}$ & Like over head & $\begin{array}{l}\text { There may be a dilution of } \\
\text { the virus, but it is still a } \\
\text { useful sample. }\end{array}$ \\
\hline 3. Both Nasal/Pharyngeal swab & Required & On ice pack. & Like over head & $\begin{array}{l}\text { The virus was } \\
\text { detected in this type of } \\
\text { sample }\end{array}$ \\
\hline 4. Nasopharyngeal aspirate (NPA) & Not Required & $\begin{array}{l}\text { On ice pack. } \\
\text { In case of delay in processing sample in lab } \\
\text { of }>24 \text { hours apply frozen with dry ice }\end{array}$ & Like over head & \\
\hline 5. Swab form Nasopharynx & Required & On ice pack. & Like over head & \\
\hline $\begin{array}{l}\text { 6. Naturally produced sputum } \\
\text { (additional risk of infection for } \\
\text { healthcare professionals) }\end{array}$ & Not Required & $\begin{array}{l}\text { On ice pack. } \\
\text { In case of delay in processing sample in lab } \\
\text { of }>24 \text { hours apply frozen with dry ice }\end{array}$ & Like over head & $\begin{array}{l}\text { It is necessary to ensure that } \\
\text { the material comes from the } \\
\text { lower respiratory tract }\end{array}$ \\
\hline $\begin{array}{l}\text { 7. Serology for virus detection or } \\
\text { serology: whenever possible, collect } \\
\text { pooled samples. } \\
\text { Acute - first week of illness } \\
\text { Convalescent - ideally 3-4 weeks later }\end{array}$ & Not Required & On ice pack or frozen section. & Like over head & \\
\hline 8. Aspirate from Trachea & Not Required & $\begin{array}{l}\text { On ice pack. } \\
\text { In case of delay in processing sample in lab } \\
\text { of }>24 \text { hours apply frozen with dry ice }\end{array}$ & As over head & \\
\hline 9. Blood & $\begin{array}{l}\text { Not Required / } \\
\text { Anticoagulant } \\
\text { (EDTA) }\end{array}$ & On ice pack & As over head & $\begin{array}{l}\text { For the detection of } \\
\text { viruses, especially in the } \\
\text { first week of illness. }\end{array}$ \\
\hline
\end{tabular}

The samples (refrigerated between 4 and 8 degrees Celsius) must arrive at the laboratory immediately after collection and must be classified within 24-72 hours of collection. If delay in transporting respiratory tract samples or serum is there, freezing them on dry ice (at $-70^{\circ} \mathrm{C}$ or less) is recommended until the samples are shipped.

Some of the instructions from different specimens for collection, handling and transportation to obtain an accurate and authentic corona virus report (COVID-19) are mentioned above in Table 2 (WHO, 2020b).

\section{Diagnostic Tools}

Various advances in the field of diagnosis have been made for SARS-CoV-2 timely detection and effective monitoring of COVID19 , which altogether could aid in timely follow up of appropriate disease prevention and control measures to halt the spread of the current pandemic. Advantages, limitations and challenges of different diagnostics need to be considered for effective implementation of various diagnosis programs (Afzal, 2020; Ai et al., 2020; Cheng et al., 2020; Dinnes et al., 2020; Natesan et al., 2020; Ravichandran et al., 2020; Tang et al., 2020; Udugama et al., 2020). Viral diagnostic tests must be done in adequately equipped laboratories by personnel well qualified and trained in the appropriate technical and safety procedures. The diagnosis of viral infection mainly applies two serological immunoassay rapid diagnostic test (RDT) methods and the quantitative chain reaction of reverse transcription polymerase (RT-qPCR). Although most of the current assays upstream of the $\mathrm{E}$ (upE) protein gene are considered highly sensitive and open reading frame $1 \mathrm{~b}$ (ORF $1 \mathrm{~b}$ ) assays as an application of the same sensitivity and open reading frame 1a (ORF 1a) as less sensitive (Peeri et al., 2020; WHO, 2020a; Djalante et al., 2020; Lippi et al., 2020).

5.1 Serological immunological tests (virus specific antigens or antibodies):

\subsubsection{Rapid Lateral Flow Immunoassay}

\subsubsection{Detection of virus-specific antigens:}

In this test, antibodies attached to the rifle bind to the SARS-CoV2 virus brand antigen in an individual's serum / respiratory serum samples. The tests mentioned above are perfect for identifying an acute or immediate infection. Earlier studies suggest that An-Suei Yang and teammates, researchers at the Genomics Research 
Center, Academia in Taipei, Taiwan invented monoclonal antibody against $\mathrm{N}$ protein of SARS-CoV-2 which when assembled and certified, could be the basis of an antigen based rapid immunoassay for the diagnosis of COVID-19. Similarly the study also suggest, Sona Nanotech (Halfax, Canada) in collaboration with GE Health Life Sciences has been working on the S protein (S1 domain) of the virus in developing a rapid immunoassay that could detect antigens of SARS-CoV-2 in about 5-15 minutes and (Lee et al., 2020). The recent study done by Carter et al., 2020 suggest that Canada has approved Rapid SARS-CoV-2 antigen detection test developed by Nova Scotiathat detect S1 domain of S protein in nasal swab. The study also suggest many antigen detection test kit like COVID-19 Ag ECO test, Standard Q COVID-19 Ag, Wantai SARS-CoV-2, COVID-19 Ag Respi-strip, Standard F COVID-19 Ag FIA etc. has been approved by Brazil, South Korea, Australia, Belgium, South Korea respectively.The susceptibility of these tests can be assumed to differ from $34 \%$ to $80 \%$ as false negative results are observed. This study was not recently approved by WHO for patient care, except for the analysis of its possible diagnostic efficacy (WHO, 2020b).

\subsubsection{Detection of virus-specific antibodies}

IgG / IgM serological tests identify human antibodies which are proteins belonging to various classes of immunoglobins which are more stable than viral RNA. As a result, IgG / IgM samples are less susceptible to decomposition during collection, transport, storage and analysis than RT-qPCR. They are generally evenly distributed in human blood, serological samples have much smaller variations than nasopharyngeal viral RNA samples and can be easily collected with a slight discomfort of phlebotomy for the patient. Persist in the blood for several weeks / months after the onset of symptoms. Some study suggest that seroconversion in $50 \%$ of patient exist after 7 days and and in all patient after 14 days of onset of symptoms. The study shows IgM antibody start to appear from 7 days after onset of symptoms and may exists in blood for at least 21 days and vanished then after whereas $\operatorname{IgG}$ antibody start to become visible from 14 days after onset of symptoms and may exists in blood for a long period. The study regarding antibody response during the infection period and after recovery period desperately required (Rando et al., 2020). The study regarding antibody detection was not recently approved by WHO for patient care except disease control and epidemiological research (WHO, 2020a). Although the serological IgM / IgG test alone may not be sufficient to diagnose COVID-19, they can be a valuable diagnostic tool when combined with RT-qPCR (Djalante et al., 2020).

\subsubsection{Enzyme Linked Immuno Sorbent Assay (ELISA)}

The previous established serological assay named ELISA that is highly sensitive and specific to detect IgG and IgM antibodies against SARS-CoV-2 can be taken as another better diagnostic tool. The Liu et al. (2020) demonstrated positive rate for antibody IgM and $\operatorname{IgG}$ detection by ELISA were $80 \%$ and $82.2 \%$ respectively concluding ELISA can be highly sensitive tool for the diagnosis of COVID-19 patients in serum sample. Another study of Jaaskelainen et al. (2020) suggested the overall specificities were $91.9 \%$ and $73 \%$ for IgG and IgA ELISAS, respectively after 11-12 day of symptom onset concluding this method can be important for screening COVID-19.

\subsection{Quantitative reverse transcription polymerase chain reaction (RT-qPCR) :}

RT-qPCR is a highly sensitive test for the identification of the SARS-CoV-2 virus but has its limitations as it requires high quality nasopharyngeal swabs that contain sufficient quantities of viral load RNA. The identification of SARS-CoV-2 by RT-PCR in various clinical samples can give us an idea of the isolation rate of the virus in the patient mentioned in Table 3 (Lippi et al., 2020;

Table 3 Detection of SARS-CoV-2 by RT-PCR in Respiratory samples and in different clinical samples

\begin{tabular}{|c|c|c|c|}
\hline & \multirow{2}{*}{$\begin{array}{l}\text { Respiratory } \\
\text { Samples only }\end{array}$} & \multicolumn{2}{|c|}{ Positive Results (\%) } \\
\hline & & $\begin{array}{l}\text { Severe } \\
\text { Cases }\end{array}$ & $\begin{array}{l}\text { Mild } \\
\text { Cases }\end{array}$ \\
\hline \multirow{4}{*}{ 0-7 Day } & Throat Swab & 60.00 & 61.30 \\
\hline & Nasal Swab & 73.30 & 72.10 \\
\hline & Sputum & 89.90 & 82.20 \\
\hline & BALF & 0 & 0 \\
\hline \multirow{4}{*}{ 8-14 Day } & Throat Swab & 50.00 & 29.60 \\
\hline & Nasal Swab & 72.30 & 53.60 \\
\hline & Sputum & 83.30 & 74.40 \\
\hline & BALF & 100 & 0.00 \\
\hline \multirow{4}{*}{$\geq 15$ Day } & Throat Swab & 36.80 & 11.10 \\
\hline & Nasal Swab & 50.00 & 54.50 \\
\hline & Sputum & 61.10 & 42.90 \\
\hline & BALF & 78.60 & 0.00 \\
\hline \multirow{9}{*}{ N/A } & $\begin{array}{l}\text { Different Samples } \\
(\mathrm{n}=\text { total numbers) }\end{array}$ & \multicolumn{2}{|c|}{$\begin{array}{c}\text { Positive Results } \\
\text { Percentage and } \\
\text { Numbers of Samples }\end{array}$} \\
\hline & BALF $(n=15)$ & \multicolumn{2}{|c|}{$93.00(14)$} \\
\hline & $\begin{array}{c}\text { Firbobronchoscope } \\
\text { Brush Biopsy }(\mathrm{n}=13)\end{array}$ & \multicolumn{2}{|c|}{$46.00(6)$} \\
\hline & Sputum $(n=104)$ & \multicolumn{2}{|c|}{$72.00(75)$} \\
\hline & Nasal Swabs $(\mathrm{n}=8)$ & \multicolumn{2}{|c|}{$63.00(5)$} \\
\hline & $\begin{array}{c}\text { Pharyngeal Swabs } \\
(\mathrm{n}=398)\end{array}$ & \multicolumn{2}{|c|}{$32.00(126)$} \\
\hline & Feces $(n=153)$ & \multicolumn{2}{|c|}{$29.00(44)$} \\
\hline & Blood $(n=307)$ & \multicolumn{2}{|c|}{$1.00(3)$} \\
\hline & Urine $(\mathrm{n}=72)$ & \multicolumn{2}{|c|}{$0.00(0)$} \\
\hline
\end{tabular}


Table 4 Genomic objective, area, limits, preferred samples and conservation phase recommended by WHO and CDC

\begin{tabular}{|c|c|c|c|c|}
\hline $\begin{array}{l}\text { Who Recommended } \\
\text { Genomic Target }\end{array}$ & Area & Limitations & Preferred Samples & Storage \\
\hline Envelope genome & $1^{\text {st }}$ underline Screening & 3.9 copies $\mathrm{x}$ reactions & \multirow{2}{*}{$\begin{array}{l}\text { Swab from Nasopharynx and } \\
\text { Oropharynx or wash in } \\
\text { ambulatory patients }\end{array}$} & \multirow[t]{2}{*}{$\leq 5$ Days: $2-8{ }^{\circ} \mathrm{C}$} \\
\hline Nucleocapsid genome & $\begin{array}{l}\text { Additional Confirming } \\
\text { Test }\end{array}$ & Not applicable & & \\
\hline $\begin{array}{l}\text { RNA dependent RNA- } \\
\text { polymerase gene }\end{array}$ & Confirmatory Test & 3.6 copies $\mathrm{x}$ reaction & $\begin{array}{l}\text { Lower respiratory specimens } \\
\text { (Sputum, Endotracheal sample } \\
\text { or Bronchoalveolar Lavage) }\end{array}$ & $\begin{array}{l}>5 \text { Days: } \leq 70^{\circ} \mathrm{C} \\
\text { (Dry Ice) }\end{array}$ \\
\hline \multicolumn{5}{|l|}{ CDC RECOMMENDED } \\
\hline $\begin{array}{l}\text { N1/N2/N3 Gene } \\
\text { Fragments }\end{array}$ & Combination Test & 1.0-3.2 Copies $/ \mu \mathrm{L}$ & $\begin{array}{l}\text { Swab from Nasopharyx and } \\
\text { Oropharynx, Sputum. }\end{array}$ & $\leq 4$ Day : $4^{\circ} \mathrm{C}$ \\
\hline Ribonuclease $\mathrm{P}$ genome & Control Test & Not applicable & $\begin{array}{l}\text { Aspirate from Lower } \\
\text { respiratory tract BALF, Wash } \\
\text { or Aspirate from Nasopharynx } \\
\text { or Aspirate from Nose. }\end{array}$ & $>4$ Days $: \leq 70^{\circ} \mathrm{C}$ \\
\hline
\end{tabular}

Zhai et al., 2020; Yang et al., 2020; Wang et al., 2020). In addition to the pre-analytical failure, the analytical failure deserves a specific approach that includes a focus on active viral recombination, the use of sufficiently authentic assays, a genuine adhesion of primer and probe, suitable material (Lippi et al., 2020). It may also depend on the timing of the patient's sample test, the duration of the infection with the onset of symptoms, and the sampling techniques also vary significantly from one medical staff to another. It also required highly qualified personnel to perform complex RNA and PCR extraction phases. Due to the sufficient amount of viral RNA, RT-qPCR can give a false negative test result which would not be a problem when analyzing some samples, but becomes a problem related to a global pandemic with potentially millions of people to analyze. For the diagnostic validity of the RT-PCR, the detection of the genes by WHO and CDC are listed in Table 4 (Lippi et al., 2020) showings the comparison of the real-time diagnostic test for the reverse transcription polymerase chain reaction (rRT -PCR) by WHO and CDC for confirmation of COVID-19 (Lippi et al., 2020). Figure 1 shows the viral RNA load present in different clinical samples detected by the molecular assay RT-PCR in descending order (Yang et al., 2020; Wang et al., 2020).

\subsection{Computerized chest tomography (CT) scan: -}

Computed chest tomography is a normal non-crossover tomography system and has been crucial in identifying and administering patients with COVID-19. Recently established accessible data conclude the results of chest computed tomography (CT) images, including frosted glass opacity, consolidation, bilateral impairment, multifocal organized pneumonia, delivery and diffuse diffusion at the time of initial symptoms (Lee et al., 2020). Shi and teammates also described the existence of unilateral opacities of the frosted glass in 15 asymptomatic cases with SARSCoV-2 infection, concluding that there may be changes in the characteristics of CT before symptoms begin (Lee et al., 2020). The Ai et al. (2020) suggests that $97 \%$ of cases verified by the RTPCR test revealed positive CT characteristics. Overall, CT of the chest indicates that it is highly reliable and acts as a crucial detection device for symptomatic, asymptomatic symptoms and also in cases with false negative RT-PCR results (Lee et al., 2020; Rando et al., 2020; Sheridan, 2020; Tang et al., 2020).

\subsection{CRISPR (Clustered regularly interspaced short palindromic repeats) Based diagnosis:}

To expand the availability of the trial, the U.S. agency Mammoth Biosciences and Sherlock Biosciences have modified their CRISPR-Cas 12 technology for the identification of SARS-CoV-2 infection. Guo et al. (2020) reported, Sherlock ${ }^{\mathrm{TM}}$ CRISPR SARSCoV-2 kit developed by Sherlock Biosciences works by programming CRISPR molecule to detect the presence of target genetic marker and has been approved from US Food and Drug Administration on May 6 for emergency use to detect SARS-CoV2. The study also suggested another CRISPR- based assay developed by Mammoth Biosciences named SARS-CoV-2 DNA Endonuclease - Targeted CRISPR Trans Reporter (DETECTR) is very easy to use and accurate tool for the diagnosis of COVID-19. This diagnostic tool has a reliability of over 70-300 copies of the selected RNA / $\mu 1$, which requires a sample, an equipment and a performance result in about 30 minutes. In this test, the RNA is extracted, refined and enhanced by the isothermal nucleic acid amplification technique and the RNAs are described to support the specific part of the genomic sequence such as N, E and RdRp, part of SARS-CoV-2 and results in DNA and ssDNA cut by Cas 12 . The result is interpreted in the lateral flow test indicated by the 


\section{Bronchoalveolar Lavage Fluid}

\section{In Severe cases only (Mechanical Ventilated Patients)}

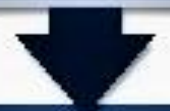

\section{Sputum Sample}

In both Severe and Mild cases (Most Accurate for lab diagnosis)

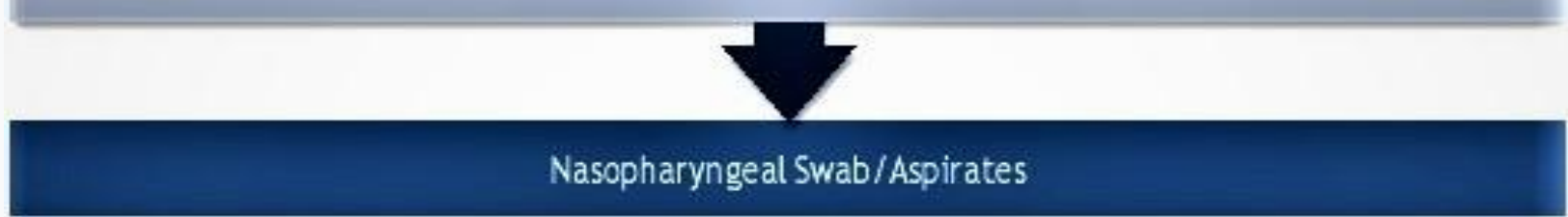

In both Severe and Mild Cases (Most significant if above two samples are difficult to collect)

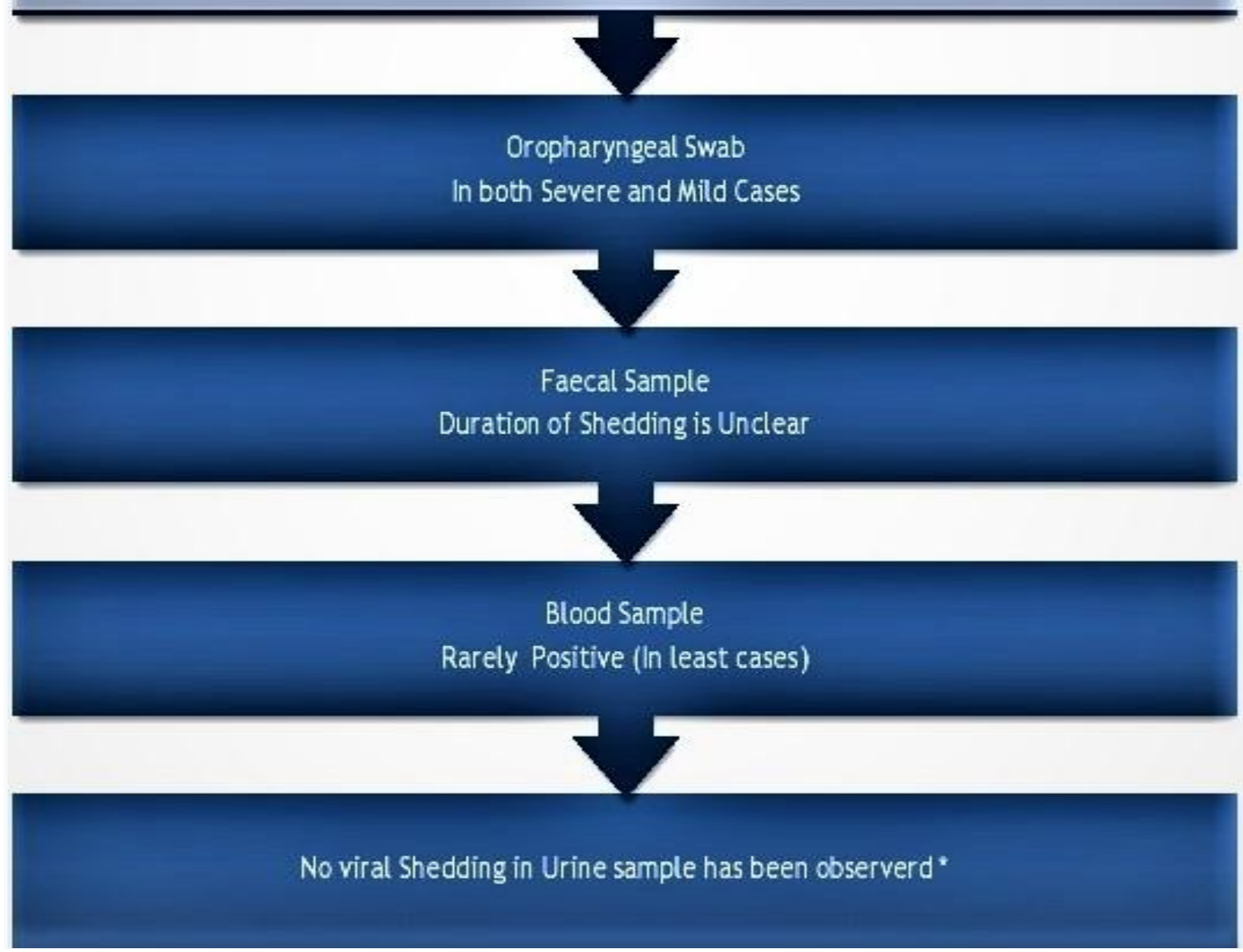

Figure 1 Flow chart showing the viral RNA load present in different clinical samples detected by the molecular assay RT-PCR in descending order

Journal of Experimental Biology and Agricultural Sciences http://www.jebas.org 
virus. Many studies revealed $100 \%$ and $91.7 \%$ as a positive predictive value and a negative predictive value respectively and were considered primarily combative with the CDC test using RTPCR (Rando et al., 2020).

5.5 Matrix- Assisted Laser Desorption/Ionization Mass Spectrometry and Machine Learning Analysis (MALDI-MS) Based Diagnosis

This technique is reliable for the detection of highly sensitive and specific strains via proteomic profiling and is based on reference spectra of strains and bioinformatics as well (Smith et al., 2017). The article "Detection of SARS-CoV-2 in nasal swabs using MALDI-MS" published in nature biotechnology revealed that MALDI-MS and machine learning analysis is very useful and reliable technique to identify SARS-CoV-2 in nasopharyngeal swab. The study showed that among 362 total samples (211 positive and 151 negative for the virus by RT-PCR), this method revealed $93.9 \%$ accuracy with only $7 \%$ false positive and $5 \%$ false negative results. This method is well developed and trusted in numerous countries for regular diagnosis of different fungal and bacterial strains in clinical laboratories but has not been utilized for diagnosis of COVID-19 till date but could be very essential and cost effective tool for the diagnosis of COVID-19 for future perspectives (Nachtigall et al., 2020).

\subsection{Reverse Transcriptional Loop-mediated Isothermal Amplification (RT-LAMP) Based Diagnosis}

This technique involves the addition of specimen to the tube where the gene is amplified using large number of specific primers and is identified by colour, turbidity and fluorescence. Yu et al. (2020) developed an isothermal LAMP based tool- iLACO and amplified ORF1ab gene using 6 primers that detected RNA equal to 10 copies of SARS-CoV-2 within 15-40 minutes. The study revealed the sensitivity equivalent to Taqman based $\mathrm{qPCR}$ assay and is appropriate for the diagnosis of COVID-19 in developing countries where laboratory sources are lacking (Yu et al., 2020).

\subsection{Point of Care (POC) RNA- Based Diagnosis}

The idea of this tool is extracted from preceding research on paper based nucleic acid identification using RT-LAMP test. The study done by Yang et al (2020) explained that RNA-based POC when merged with both paper based POC device and LAMP test and combined with a smart phone device could be highly sensitive tool for COVID-19 diagnosis. The development of LAMP based assay in a paper based system, walls of the reaction tube, test-strip or LAMP on a chip with advanced microfluids, sensors and computer integrations may transform the idea of POCT for detection of SARS-CoV-2 (Augustine et al., 2020). This tool could be easily used by people in their home and observe a visible colorimetric assay results and provide information to health professionals through the internet and pace the process of taking clinical decisions and decrease the requirement of trained manpower (Kubina \& Dziedzic, 2020; Yang et al., 2020).

\subsection{Gene Xpert Based Diagnosis}

Cephed is an American molecular diagnostics company that has invented an automated Gene Xpert molecular assay named Xpert Xpress for the qualitative detection of SARS- CoV-2. This method targets multiple viral genomes and provides sensitivity of more than $99 \%$ and is a 45 minutes random access assay. This tool has been utilized in many developed countries and developing countries like Nepal for screening of critically ill patients (Moran et al., 2020)

\subsection{Virus Isolation}

Various cell lines like human airway epithelial cells, vero cells (CCL81, E6), Human liver cells (HUH 7.0) etc. have been found very significant for in vitro isolation of virus that can be visualized by transmission electron microscope (Pathak et al., 2020). This technique has a very high value in research but cannot be utilized as routine diagnostic tool.

\subsection{Miscellaneous Diagnostic Tools to Combat COVID-19}

\subsubsection{Geographical Information System (GIS) Based Mapping and Tracking}

GIS, AI (Artificial Intelligence) and data enabled analytics dashboards have been developed by different countries of the world to map and track the aggressiveness of COVID-19 outbreak (Arab-Mazar et al., 2020; Devasia et al., 2020)

\subsubsection{Prediction Model Tools}

Prediction Model Risk of Bias Assessment (PROBAST) and Critical Appraisal and data extraction for systematic reviewers of prediction modelling studies (CHARMS) are the few prediction models that could help in identification of people who are at high risk of infection, diagnosis and prognosis of COVID-19. However the study suggest that it is very necessary to invent and validate novel and authentic predictors for clinical decision in order to avoid biasness and harm (Wynants et al., 2020)

\section{Discussion}

Corona viruses are a group of viruses belonging to the order Nidovirales and to the Coronaviridae family, of which 4 genera are substantially related to humans and classified on the basis of genetic phylogeny (Siddell, 1995; Kasmi et al., 2020; Shereen et al., 2020). Initial evidence of SARS-CoV-1 appeared in 2002 and quickly spread to 32 countries and territories, after the planet faced an increase in MERS-CoV in 2012. In two of these epidemics, viruses presumably had origin inbats and through contaminated human 
intermediate hosts (Kasmi et al., 2020). The current spread of SARS CoV-2 is the third recorded invasion of an animal corona virus in humanity in recent decades (Shereen et al., 2020; Mahy\& Van Regenmortel, 2010; Drexler et al., 2014). When it came to the COVID-19 pandemic, the issue of laboratory tests is crucial. The size analysis was painfully inadequate for the clinical trials of people with excessive risks, epidemiological analyzes and social transmission (Zhai et al., 2020). Although several companies and countries have generated, marketed and approved various assay tools for serological immunoassay, these assays are not recently approved by WHO for patient care, except for the analysis of its possible diagnostic efficacy. Special studies have established that several $\mathrm{CoVs}$ and even the dengue virus may impose false positive results (Djalante et al., 2020). A large focal point must be specified on the sensitivity, specificity and diagnosis of the test. The test based on the enzyme immunoassay of the serological IgG / IgM test indicates the existence of antibodies in the patient sample detected between 5 and 14 days after the start of the event, showing that this test is not able to recognize the contamination before the manifestation and, therefore, can give false negative results, for which the WHO recommends only validation, epidemiological investigation and monitoring. Different Corporations and research agencies have been developed and working on the development of specific monoclonal antibody against nucleocapsid and spikes protein of SARS-CoV-2 as the basis of an antigen based rapid lateral flow immunoassay which could make the screening of COVID-19 more better. Reverse transcription the quantitative PCR at present is the best applicable method for the diagnosis of COVID-19 in respiratory samples. RTPCR chooses the existence of true molecular targets for SARS-CoV2 in the sample. To date, for diagnostic reliability in the molecular test, WHO has entered the 'E' gene test as the initial line detection test, the RdRpgene as a confirmation test and the $\mathrm{N}$ gene as a secondary confirmation test, while the $\mathrm{CDC}$ has enrolled two primers from the gene set or probes N1, N2, N3 as the initial console and RNasePgene in the sample and controlled as a secondary set (Lippi et al., 2020).

The study conducted by Wang et al. (2020) reveals that the percentage of positive analysis differs based on the samples that vary from $93 \%$ in BALF, to $69.2 \%$ in sputum, to $62.5 \%$ in nasopharyngeal swab, to $31,7 \%$ in the oropharyngeal sample, to $29 \%$ in faeces, to $1 \%$ in blood and no viral load detected in urine sample. The data are shown in Table 3 (Wang et al., 2020), similarly, the study conducted by Yang et al., (2020) shows the maximum positive value in BALF $(78.6 \%$ to $100 \%$ in severe cases at $\geq 15$ days and 8-14 days after onset of illness, respectively) followed by sputum $(74.4 \%-88.9 \%)$, buffer nasopharyngeal $(53.6 \%-72.3 \%)$ during the first 14 days after the onset of the disease as shown in Table 4 (Yang et al., 2020). The current investigation on 20 SARS-CoV-2 infected patients revealed that the virus was not detected from faecal samples despite of excessive RNA level, hence the further study need to be done for RT-PCR positive results in faecal samples in order to correlate with viral isolation (Rando et al., 2020; Sheridan, 2020). Also the viral shedding in blood sample throughout the COVID-19 illness is very rare but it also needs to be investigated further. However analyzing samples from multiple sites can improve sensitivity and reduce the false negative test result.

Various studies have shown that CT of the chest has excessive precision and rhythm. The distinctive features prevalent in computed tomography are useful in the diagnosis of SARS-CoV-2 pneumonia. It could be the main tool in patients with false negative RT-PCR results, asymptomatic and symptomatic cases (Lee et al., 2020). Diagnosis based on CRISPR can be an additional sensitive diagnostic tool that can facilitate the detection of SARS-CoV-2. High predictive value of this study could aid to avoid the consumption of time and helps a high value (Rando et al., 2020; Sheridan, 2020; Tang et al., 2020). Diagnosis based on MALDIMS, RT-LAMP, Gene Xpert can be other additional highly sensitive tool to identify SARS-CoV-2 in nasopharyngeal swab specimen because of its high diagnostic accuracy (Nachtigall et al., 2020; Yu et al., 2020). Other Tool like GIS, artificial intelligence (AI) and prediction model tool could help to combat COVID-19.

\section{Conclusion}

This new outbreak of viruses has challenged the world's economic, medical and public health infrastructures. Therefore, applying different methods of diagnosis of patients, it will be a first line to combat Corona virus diseases.

In general, the results of the RT-qPCR and IgM / IgG serological tests can improve the accuracy of the diagnosis of COVID-19. While the RT-qPCR test may be appropriate for the detection of SARS-CoV-2 virus during the acute phase, IgG / IgM may be an adequate test during the chronic phase. The commercial availability of SARS-CoV-2 antigen based lateral flow immunoassay with more sensitivity and specificity can aid high value in the screening of COVID-19 therefore serological immunological analysis must be adequately established. Further research is needed on the correlation of CT characteristics with clinical severity, continuation along with its predictive value. The CRISPR-based tool can be practical in areas that are more likely to become infected. Many developing countries lack various laboratory resources and ingress to PCR kits therefore in such condition, MALDI-MS could be reliable to diagnose COVID-19.

Some studies show that the sputum sample followed by a nasopharynx sample could be more accurate for laboratory investigations of SARS-CoV-2 by molecular tests, while BALF is a mandatory sample for the study in critical cases. Also the viral RNA may not be detected in patients who are on antiviral therapy therefore in such cases BALF may be the best sample for examination of viral load for further monitoring of the patients. The 
RT-PCR positivity in faecal samples and blood samples need to be investigated further in order to conclude the duration of viral shedding and also in order to correlate with viral transmission and systemic infection respectively. Overall detailed data on the characteristics of the assay and the remains of various specimens are needed to balance diagnostic merit and clinical protection and to model the system for the assay strategy that can help counter SARS-CoV-2 infection. A more rigorous purification of the viral genome would be necessary to recognize a greater area in the molecular targets that can be delegated to extend the feasibility of high altitude diagnostic reliability.

\section{Acknowledgment}

We highly acknowledge Dr. Rupendra Shrestha (Department of Genetics, Albert Einstein College of Medicine) for his suggestion to improve the manuscript. In addition, we like to acknowledge Pokhara University, Purbanchal University, and Mayadevi Technical College (CTEVT), Medicross Diagnostics Pvt.Ltd., Nepal, for their kind support.

\section{Conflict of interest}

The authors of this manuscript declare that there is no conflict of interests.

\section{Funding source}

There is no any funding for this work.

\section{References}

Afzal A (2020) Molecular diagnostic technologies for COVID-19: Limitations and challenges. Journal of Advanced Research 10.1016/j.jare.2020.08.002. doi:10.1016/j.jare.2020.08.002.

Ai JW, Zhang Y, Zhang HC, Xu T, Zhang WH (2020) Era of molecular diagnosis for pathogen identification of unexplained pneumonia, lessons to be learned. Emerging Microbes \& Infections 9(1): 597-600.

Ai T, Yang Z, Hou H, Zhan C, Chen C, Lv W, Tao Q, Sun Z, Xia L (2019) Correlation of chest CT and RT-PCR testing in corona virus disease 2019 (COVID-19) in China: a report of 1014 cases. Radiology. 2020 Feb 26:200642.

Amanat F, Krammer F (2020) SARS-CoV-2 vaccines: status report. Immunity 52(4): 583-589.

Arab-Mazar Z, Sah R, Rabaan AA, Dhama K, Rodriguez-Morales AJ (2020) Mapping the incidence of the COVID-19 hotspot in Iran - Implications for Travellers. Travel Medicine and Infectious Disease 34:101630.doi:10.1016/j.tmaid.2020.101630.
Augustine R, Hasan A, Das S, Ahmed R, Mori Y, Notomi T, Kevadiya BD, Thakor AS (2020) Loop-mediated isothermal amplification (Lamp): A rapid, sensitive, specific, and costeffective point-of-care test for coronaviruses in the context of covid-19 pandemic. Biology, 9(8), 182.

Cafekar A, Fielding BC (2018) MERS-CoV: understanding the latest human coronavirus threat. Viruses 10(2):93.

Carter LJ, Garner LV, Smoot JW, Li Y, Zhou Q, Saveson CJ, Sasso JM, Gregg AC, Soares DJ, Beskid TR, Jervey SR, Liu C (2020) Assay Techniques and Test Development for COVID-19 Diagnosis. ACS Central Science 6(5):591-605. doi: 10.1021/acscentsci.0c00501.

Cascella M, Rajnik M, Cuomo A, Dulebohn SC, Di Napoli R (2020) Features, evaluation and treatment coronavirus (COVID19). InStatpearls [internet] 2020 Mar 8.StatPearls Publishing.

Cheng MP, Papenburg J, Desjardins M, Kanjilal S, Quach C, Libman M, Dittrich S, Yansouni CP (2020) Diagnostic Testing for Severe Acute Respiratory Syndrome-Related Coronavirus-2: A Narrative Review. Annals of Internal Medicine M20-1301.

Devasia JT, Lakshminarayanan S, Kar SS (2020) How Modern Geographical Information Systems Based Mapping and Tracking Can Help to Combat Severe Acute Respiratory Syndrome Coronavirus 2 (SARS-CoV-2) Pandemic around the World and India. International Journal of Health Systems and Implementation Research 10;4(1):30-54.

Dhama K, Khan S, Tiwari R, Sircar S, Bhat S, Malik YS, Singh KP, Chaicumpa W, Bonilla-Aldana DK, Rodriguez-Morales AJ (2020a) Coronavirus Disease 2019-COVID-19. Clinical Microbiology Reviews 33(4):e00028-20. doi: 10.1128/CMR.00028-20.

Dhama K, Patel SK, Pathak M, Yatoo MI, Tiwari R, Malik YS, Singh R, Sah R, Rabaan AA, Bonilla-Aldana DK, RodriguezMorales AJ (2020b) An update on SARS-CoV-2/COVID-19 with particular reference to its clinical pathology, pathogenesis, immunopathology and mitigation strategies. Travel Medicine and Infectious Disease 101755. doi: 10.1016/j.tmaid.2020.101755.

Dinnes J, Deeks JJ, Adriano A, Berhane S, Davenport C, Dittrich S, Emperador D, Takwoingi Y, Cunningham J, Beese S, Dretzke J, Ferrante di Ruffano L, Harris IM, Price MJ, Taylor-Phillips S, Hooft L, Leeflang MM, Spijker R, Van den Bruel A (2020) Cochrane COVID-19 Diagnostic Test Accuracy Group. Rapid, point-of-care antigen and molecular-based tests for diagnosis of SARS-CoV-2 infection. Cochrane Database of Systematic Reviews8:CD013705.doi: 10.1002/14651858.CD013705.

Djalante R, Lassa J, Setiamarga D, Mahfud C, Sudjatma A, Indrawan M, Haryanto B, Sinapoy MS, Rafliana I, Djalante S, 
Gunawan LA (2020) Review and analysis of current responses to COVID-19 in Indonesia: Period of January to March 2020. Progress in Disaster Science 2020 Apr 4:100091.

Drexler JF, Corman VM, Drosten C (2014) Ecology, evolution and classification of bat coronaviruses in the aftermath of SARS. Antiviral research 2014 Jan 1;101:45-56.

Guo L, Sun X, Wang X, Liang C, Jiang H, Gao Q, Dai M, Qu B, Fang S, Mao Y, Chen Y, Feng G, Gu Q, Wang L, Wang RR, Zhou Q, Li W (2020) SARS-CoV-2 detection with CRISPR diagnostics. Cell Discovery 6(1): 1-4.

Jääskeläinen AJ, Kekäläinen E, Kallio-Kokko H, Mannonen L, Kortela E, Vapalahti O, Kurkela S, Lappalainen M (2020) Evaluation of commercial and automated SARS-CoV-2 IgGand IgA ELISAs using coronavirus disease (COVID-19) patient samples. Eurosurveillance 25(18): 2000603.

Kasmi Y, Khataby K, Souiri A, Ennaji MM (2020) Coronaviridae: 100,000 Years of Emergence and Reemergence. In: Ennaji MM (Ed) Emerging and Reemerging Viral Pathogens, Academic Press, Pp. 127-149. doi: 10.1016/B978-0-12-819400-3.00007-7.

Kubina R, Dziedzic A (2020) Molecular and Serological Tests for COVID-19 a Comparative Review of SARS-CoV-2 Coronavirus Laboratory and Point-of-Care Diagnostics. Diagnostics 10(6): 434.

Lee EY, Ng MY, Khong PL (2020) COVID-19 pneumonia: what has CT taught us?. The Lancet Infectious Diseases 20(4):384-5.

Lippi G, Simundic AM, Plebani M (2020) Potential preanalytical and analytical vulnerabilities in the laboatory diagnosis of coronavirus disease 2019 (COVID-19).Clinical Chemistry and Laboratory Medicine (CCLM) 2020 Mar 16;1(ahead-of-print).

Liu W, Liu L, Kou G, Zheng Y, Ding Y, Ni W, Wang Q, Tan L, Wu W, Tang S, Xiong Z, Xiong Z (2020) Evaluation of nucleocapsid and spike protein-based enzyme-linked immunosorbent assays for detecting antibodies against SARSCoV-2. Journal of Clinical Microbiology 58(6):e00461. DOI: $10.1128 / \mathrm{JCM} .00461-20$

Mahy BW, Van Regenmortel MH (Ed.) (2010) Deskencyclopedia of human and medical virology. Academic Press; 2010 May 21.

Malik YS, Kumar N, Sircar S, Kaushik R, Bhat S, Dhama K, Gupta P, Goyal K, Singh MP, Ghoshal U, El Zowalaty ME, O R V, Yatoo MI, Tiwari R, Pathak M, Patel SK, Sah R, RodriguezMorales AJ, Ganesh B, Kumar P, Singh RK. (2020) Coronavirus Disease Pandemic (COVID-19): Challenges and a Global Perspective. Pathogens 9(7):519. doi: 10.3390/pathogens9070519.
Meo SA, Alhowikan AM, Al-Khlaiwi T, Meo IM, Halepoto DM, Iqbal M, Usmani AM, Hajjar W, Ahmed N (2020) Novel coronavirus 2019-nCoV: prevalence, biological and clinical characteristics comparison with SARS-CoV and MERS-CoV. European Review for Medical and Pharmacological Sciences 24(4):2012-9.

Moran A, Beavis KG, Matushek SM, Ciaglia C, Francois N, Tesic V, Love N (2020) The detection of SARS-CoV-2 using the cepheidxpertxpress SARS-CoV-2 and Roche cobas SARS-CoV-2 assays. Journal of Clinical Microbiology.2020 Apr 17.

Nachtigall FM, Pereira A, Trofymchuk OS, Santos LS (2020) Detection of SARS-CoV-2 in nasal swabs using MALDIMS. Nature Biotechnology 2020;10.1038/s41587-020-0644-7. doi:10.1038/s41587-020-0644-7

Natesan S, Bhatia R, Sundararajan A, Dhama K, Malik YS, Vora K (2020) Ramping up of SARS CoV-2 testing for the diagnosis of COVID-19 to better manage the next phase of pandemic and reduce the mortality in India . Virusdisease19.doi:10.1007/s13337-020-00622-x

Pathak M, Patel SK, Rana J, Tiwari R, Dhama K, Sah R, Rabaan AA, Bonilla-Aldana DK, Rodriguez-Morales AJ (2020) Global threat of SARS-CoV-2/COVID-19 and the need for more and better diagnostic tools. Archives of Medical Research 2020 Apr 15;51.

Peeri NC, Shrestha N, Rahman MS, Zaki R, Tan Z, Bibi S, Baghbanzadeh M, Aghamohammadi N, Zhang W, Haque U (2020) The SARS, MERS and novel coronavirus (COVID-19) epidemics, the newest and biggest global health threats: what lessons have we learned?. International Journal of Epidemiology 49: 717-726. DOI: https://doi.org/10.1093/ije/dyaa033.

Petrosillo N, Viceconte G, Ergonul O, Ippolito G, Petersen E (2020) COVID-19, SARS and MERS: are they closely related?.Clinical Microbiology and Infection 26: 729-734.

Rando HM, Greene CS, Robson MP, Boca SM, Wellhausen N, Lordan R, Brueffer C, Ray S, Lucy D, McGowan A, Gitter A (2020) SARS-CoV-2 and COVID-19: An Evolving Review of Diagnostics and Therapeutics. Manubot; 2020 Apr 17. Available on https://greenelab.github.io/covid19-review/.

Ravichandran K, Anbazhagan S, Singh SV, Agri H, Rupner RN, ObliRajendran VK, Dhama K, Singh BR (2020) Global Status of COVID-19 Diagnosis: An Overview. Journal of Pure and Applied Microbiology 14(suppl 1):879-892. doi: 10.22207/JPAM.14.SPL1.25

Shereen MA, Khan S, Kazmi A, Bashir N, Siddique R (2020) COVID-19 infection: origin, transmission, and characteristics of human coronaviruses. Journal of Advanced Research. 24:91-98. 
Sheridan C (2020) Fast, portable tests come online to curb coronavirus pandemic. Nature Biotechnology 38(5): 515-518. doi: 10.1038/d41587-020-00010-2.

Siddell SG (1995) The Coronaviridae. In: Siddell SG (Eds) The Coronaviridae. The Viruses. Springer, Boston, MA. https://doi.org/10.1007/978-1-4899-1531-3_1.

Smith A, Piga I, Galli M, Stella M, Denti V, Del Puppo M, Magni F (2017) Matrix-Assisted Laser Desorption/Ionisation Mass Spectrometry Imaging in the Study of Gastric Cancer: A Mini Review. International journal of Molecular Sciences 18(12): 2588; https://doi.org/10.3390/ijms18122588.

Tang YW, Schmitz JE, Persing DH, Stratton CW (2020) The laboratory diagnosis of COVID-19 infection: Current issues and challenges. Journal of Clinical Microbiology 58(6):e00512-20. doi: 10.1128/JCM.00512-20. pii: JCM.00512-20.

Udugama B, Kadhiresan P, Kozlowski HN, Malekjahani A, Osborne M, Li VYC, Chen H, Mubareka S, Gubbay JB, Chan WCW (2020) Diagnosing COVID-19: The Disease and Tools for Detection. ACS Nano 14(4):3822-3835.

Walls AC, Park YJ, Tortorici MA, Wall A, McGuire AT, Veesler D (2020) Structure, function, and antigenicity of the SARSCoV-2 spike glycoprotein. Cell 181:281-292.

Wang W, Xu Y, Gao R, Lu R, Han K, Wu G, Tan W (2020) Detection of SARS-CoV-2 in different types of clinical specimens. JAMA 323(18):1843-1844. doi:10.1001/jama.2020.3786
World Health Organization (2020a) Advice on the use of point-ofcare immunodiagnostic tests for COVID-19: scientific brief, 8 April 2020. World Health Organization; 2020.

World Health Organization (2020b) Laboratory testing for coronavirus disease 2019 (COVID-19) in suspected human cases: interim guidance, 2 March 2020. World Health Organization; 2020.

Wynants L, Van Calster B, Bonten MM, Collins GS, Debray TP, De Vos M, Haller MC, Heinze G, Moons KG, Riley RD, Schuit E (2020) Prediction models for diagnosis and prognosis of covid-19 infection: systematic review and critical appraisal. BMJ 2020; 369 doi: https://doi.org/10.1136/bmj.m1328.

Yang Y, Yang M, Shen C, Wang F, Yuan J, Li J, Zhang M, Wang Z, Xing L, Wei J, Peng L (2020) Laboratory diagnosis and monitoring the viral shedding of 2019-nCoV infections. MedRxiv.2020 Jan $1 . \quad$ DOI: https://doi.org/10.1101/2020.02.11.20021493

Yu L, Wu S, Hao X, Li X, Liu X, Ye S, Han H, Dong X, Li X, Li J, Liu J (2020) Rapid colorimetric detection of COVID-19 coronavirus using a reverse tran-scriptional loop-mediated isothermal amplification (RT-LAMP) diagnostic plat-form: iLACO. medRxiv. $2020 \quad$ Jan 1. http://dx.doi.org/10.1093/clinchem/hvaa102.

Zhai P, Ding Y, Wu X, Long J, Zhong Y, Li Y (2020) The epidemiology, diagnosis and treatment of COVID-19. International Journal of Antimicrobial Agents 55(5): 105955. DOI: https://doi.org/10.1016/j.ijantimicag.2020.105955. 